DOI: $10.22616 /$ REEP.2020.048

\title{
Experience and Awareness of upper Secondary School Students with Career Counselling in Czech Republic
}

\author{
Jitka Jirsáková ${ }^{1} \mathrm{PhDr}$.,PhD; Jiř́i Votava ${ }^{2}$ Mgr., PhD; Kamila Urban ${ }^{3}$ Mgr., $\mathrm{PhD}$ \\ Czech University of Life Sciences Prague, Institute of Education and Communication, Czech \\ Republic ${ }^{1,2,3}$; Institute for Research in Social Communication, Slovak Academy of Sciences, Slovakia ${ }^{3}$ \\ jirsakova@ivp.czu.cz'; votava@ivp.czu.cz ${ }^{2}$; urbankamila@ivp.czu.cz ${ }^{3}$
}

\begin{abstract}
This paper focuses on the reality of career guidance in the field of Czech upper secondary vocational schools. According to official state legislation and regulations, students at the end of their school attendance should have developed the skills necessary for career management. Students should also be able to find their place on the labour market. These expectations should correspond with curricula, especially in regard to the specific, cross-sectional topic: "The Man and the World of the Work." However, the reality is not satisfactory. The aim of the study is to present the first results of a questionnaire given to 370 pupils at eight selected secondary vocational schools within the project Design and Implementation of the Concept and Methodology of Career Learning in Vocational Education supported by the Technology Agency of the Czech Republic, the ETA program. The preliminary outcomes of a few selected questions regarding how respondents understand the term "career learning and guidance," their experience from specific methods/forms of career guidance and in which subjects they typically meet activities connected with preparation for their future career differ between students. Students from secondary vocational education with an apprenticeship certificate experience the least career guidance activities, which could have negative impact on their career path.
\end{abstract}

Keywords: career guidance, career counselling, career learning, pupil, secondary vocational education.

\section{Introduction}

For many current upper secondary vocational students facing numerous future opportunities is significant. They can continue with their further education or they can apply for a broad variety of job offers on the labour market. Nevertheless, expectations toward employees have been changing rapidly over the last ten years. New technologies have redefined the character of the national and global economy, so career guidance is also linked to policy goals related to learning (Watts, Sultana, 2004). In this context, some experts mention that we are facing the so-called fourth industrial revolution, where an internet of items, services and people are commonplace (Národní iniciativa..., 2015, 8). Changes have a fundamental impact on qualifications that are and will be demanded by the present and future labour market. Some authors (Saulīte, Andersone, 2016; Saulīe, Koha, 2017; Saulite, Andersone, 2019) report that the significance of career management skills increases, and it has its important position also within professional education. This is the reason why educational systems have been trying to enlarge the space for career learning and guidance (CLG). Schools are now obliged to prepare young people for new conditions, including digitalization, automatization, robotic production, globalization and changes in the socio-economic landscape.

Consequently, there has been a push in the Czech Republic to design and implement efficient systems of CLG. Thanks to European support, many analyses and surveys have been conducted in the field of career counselling in primary/secondary schools (Atli, 2016; Multon, Lapan, 1995; Vintere, Balode, 2016) and labour offices (Fischer et al., 2011; Khorshid, Alaiwy, 2016; Morey-López et al., 2015). These projects investigated the needs of pupils, parents and unemployed persons. However, Czech national projects (NÚV VIP Career I. and II., RAMPS VIP III. or POSPOLU, NIDV, FDV or NTF projects) also observed the situation of counsellors, the use of counselling services and their possibilities to provide these services for different groups of clients (Drahoňovská, Eliášková, 2011; Št’astnová, Drahoňovská, 2012; Hlad'o, Drahoňovská, 2012). It is a shame that the conclusions, findings and recommendations have not been applied at the state or local level. There has also not been enough research evidence related to the true experience of CLG among school students. The authors of this paper decided to investigate the difference between the "priority" (specific parts of school curricula) and reality of educational institutions (from the student's point of view). 
The project "Design and Implementation of the Concept and Methodology of Career Learning in Vocational Training", supported by the Technology Agency of the Czech Republic, aimed to develop and publish a generally applicable methodology of CLG in secondary vocational education. To reach this goal, the research team decided to distribute a questionnaire at the beginning of the project in order to find out the CLG needs and requirements of pupils and how existing institutions practiced CLG.

Career guidance (career counselling) is defined by the Organisation of Economic Cooperation and Development as a system of counselling services designed to assist individuals of all ages in making decisions regarding education, training, employment choices and career development at any point in their life (Lifelong Guidance Policy ..., 2015). These are practiced through in-school activities to help pupils clarify their own career goals and understand the labour market. Career counselling also includes individual or group counselling focused on educational and professional decisions. CLG has to be perceived as interrelated system which includes a wide range of interactions between counsellors and recipients (Briska, Dislere, 2018). This complex provides services to individuals who have not yet entered the labour market, jobseekers just looking for a job and those who are currently employed. One of the features of career guidance which policymakers could ensure is that all students will have access to educational, occupational and labour market information (Watts, Sultana, 2004).

In the Czech Republic, career guidance is connected to two ministries - the Ministry of Education, Youth and Sports and the Ministry of Labour and Social Affairs. The attention of this article will be paid mainly to the educational practice at schools. CLG is organized in two main ways. First of all, the Czech legislation appoints school counsellors as administrators of CLG. At second national curricular framework programmes list what has to be taught and organized in schools.

School counsellors have responsibility in two main directions: methodical supervision and information distribution.

Consulting activities include career counselling and counselling assistance in the decisions of further educational and professional career for pupils. More specifically, this includes (Vyhláška..., 2005):

- the coordination of the main areas of career counselling: career education and diagnostic-counselling activities aimed at the educational decisions of pupils,

- basic group surveys on the choice of occupation, administration, processing and interpretation of interest questionnaires within their own professional competence and analysis of preferences in the area of choice of profession of pupils,

- occupational surveys in conjunction with individual counselling,

- advising legal guardians in consideration of pupil expectations,

- cooperation with school counselling facilities in the providing of counselling services beyond the institution's competence.

The methodology includes:

- mediation of new pedagogical diagnostics and intervention methods,

- methodological assistance to schoolteachers regarding the career decisions, integration and individual educational plans of pupils,

- the transfer of professional information to teachers in the field of career counselling and special education,

- information transfer between the school and other counselling facilities in the region,

- collection of expert reports and information on pupils under the care of other counselling facilities and their provision in accordance with data protection regulations,

- the keeping of written records to document counselling activities.

Czech career guidance curriculum focuses on pupil self-knowledge, their planning of study and careers and overall preparedness for the labour market in conjunction with Humans and the World of Work at Basic schools. The thematic area of The World of Work is compulsory for all pupils in its entirety, and with respect to its focus on the selection of future professions, it is advisable that it be included in the highest forms of secondary school. The pupil learns to work with various materials and acquires basic working skills and habits (Framework Education Programme..., 2007). 
At secondary vocational schools, CLG topics are covered in the cross-curricular subject: Man, and the World of Work. This cross-curricular subject complements the knowledge and skills acquired by students in the professional component of education. It also complements the most important knowledge and skills related to its application in the world of work. It seeks to assist pupils in deciding for further professional and educational orientation, entering the labour market and exercising labour rights (Rámcové vzdělávací programy..., 2017).

Pupils at secondary vocational schools should develop their key competences for employment and entrepreneurial activities. The aim of education is to enable graduates to make optimal use of their personal and professional qualifications for successful employment in the world of work, thus building and developing their professional careers and lifelong learning capacity. Graduates should (Rámcové vzdělávací programy..., 2017):

- reflect a responsible attitude towards their own professional future and education,

- be aware of the importance of lifelong learning,

- be prepared to adapt to changing working conditions,

- have an overview of employment opportunities in the field,

- make purposeful and responsible decisions about their future professional and educational career,

- have a realistic idea of working conditions, compensation and other industry conditions,

- be able to acquire and evaluate information regarding job and educational opportunities, using advisory and mediation services from the world of work and education,

- communicate appropriately with potential employers,

- present their professional potential and their professional goals,

- know the general rights and obligations of employers and workers,

- understand the nature and principles of entrepreneurship, have an idea of the legal, economic, administrative, personal and ethical aspects of private entrepreneurship,

- be able to search and assess business opportunities in accordance with the reality of the market.

The topic content can be divided into the following units:

- characteristics of work and their application to employment alternatives, relation to study, learning outcomes, abilities, characteristics and health conditions,

- labour market, labour market indicators, general development trends, employers' requirements,

- links between the Czech education and various types of post-graduate education,

- the criteria for deciding on further professional and educational paths,

- written and verbal self-presentation on entering the labour market,

- labour Code knowledge

- the nature, forms, practices, laws and risks of entrepreneurship,

- information, counselling and mediation regarding State support for employment and unemployment,

- digital job searching strategies.

The aim of the study is to present the first results of a questionnaire given to 370 pupils at eight selected secondary vocational schools within the project Design and Implementation of the Concept and Methodology of Career Learning in Vocational Education supported by the Technology Agency of the Czech Republic, the ETA program.

\section{Methodology}

The aim of our survey was to unearth the realization of career learning and counselling in secondary vocational schools.

To explore the experiences of upper secondary vocational school students with career counselling in the Czech Republic, we distributed the questionnaire to eight high schools in four regions of the Czech Republic. The following hypotheses were established:

$\mathrm{H}_{1}$ : We expected significant differences between students' groups - that is, students from secondary vocational education with an apprenticeship certificate $(\mathrm{H})$, students from secondary vocational education with "maturita" $(\mathrm{M})$ and students from secondary vocational 
education with vocational training and "maturita" (L) - in their awareness of career counselling activities (Diagram of the..., 2019).

$\mathrm{H}_{2}$ : We expected significant differences between study programmes $(\mathrm{H}, \mathrm{M}, \mathrm{L})$ in career guidance activities carried out.

$\mathrm{H}_{3}$ : We expected significant differences between teaching subjects in the activities carried out.

We operated under the assumption that vocational schools should have different priorities and ideas for counselling work compared to general education schools (i.e. grammar school). A questionnaire, containing a total of twenty-nine items, was prepared for this research purpose. In terms of respondents' classification, the school name, field, level of education, sex and age were collected. Other questions were created to determine the relevant CLG experience and knowledge acquired during their schooling. Due to the specific focus of this output, we evaluated three questions:

1. What do students mean by career guidance?

2. Which activities have pupils already encountered in CLG?

3. In what subjects do student encounter CLG?

The first question was aimed at secondary vocational school students. We presumed that, if the school actually pursued vocational training, this would also correspond to the response of the surveyed population. Respondents chose from the following options: someone will advise me which school to choose; I'll learn how to make a lot of money; I will learn how to reach a higher position at work; I will acquire the skills needed to manage my career; I discover what I like (what interests); check what I'm good at (what skills do I have); I know what job I fit; I will learn what I need to do in order to do the job I have chosen.

The second survey question concerned the CLG activities pupils had already encountered in school. In this case, we again assumed that, if schools were to provide guidance, pupils had to have specific guidance methods and forms of experience. Respondents could choose more than one option. The following gives a specific overview of the items surveyed: individual interview with educational or career advisor; individual interview with educational or career counsellor and parents; group activities in the classroom, focused on career choice; psychological tests; lectures recognized by the school e.g. by the labour office, pedagogical-psychological counselling; programs organized outside the school (at the labour office, counselling centre or other institutions); presentation of companies at the school; excursions to companies; professional experience at contract workplaces; participation in job fairs; further education.

The question was asked to determine how the pupils' ideas and experiences about CLG may differ with other studied variables. In particular, we wondered whether there were differences in support provided to pupils in upper secondary education - who were assessed by the "maturita" examination (ISCED 354/EQF4, designated in this article in accordance with the Czech classification of letters $\mathrm{M}$ and L) and those in apprenticeships (ISCED 353/EQF3, marked in this article with a letter H) (Czech Republic Overview..., 2019; Diagram of the education..., 2017). Given graduates of H programmes continue their studies at the tertiary level, it can be assumed that they will approach school counsellors or career guidance counsellors more often than apprentices. On the other hand, we expect that less attention is paid to pupils in the $\mathrm{H}$ category, perhaps because it is assumed that they have already opted for their profession of choice, thus directly being placed into practice after training. Group L students, meanwhile, stayed on a post-secondary level. This group includes individuals who have previously completed an apprenticeship and are subsequently completing their full secondary education with school-leaving examination ("maturita").

Last, we were interested in subjects who encountered CLG. In this case, the answers could lead to a further understanding of the extent to which both CLG and teachers are involved in counselling.

A total of 370 high school students ( 218 men and 152 women) aged 16 to 23 (mean age $=18.24 ; S D=1.03$ ) participated in the research. There were 111 students from H, 158 students from M and 101 students from L.

\section{Results and Discussion}

The data was analysed in SPSS-25. We tested the first hypothesis using the Chi-Squared test. The Chi-Squared test for independence showed no significant group differences in term knowledge, 
$\chi^{2}(6, N=370)=9.96, p=0.13$. All high school students from different study programmes recognized the term career counselling in the same way.

We then asked what they imagined when they heard the term: career counselling. We conducted a Repeated Measures ANOVA. Eight possible answers were entered as a within-subjects factor (repeated measures); study programmes $(\mathrm{H}, \mathrm{M}, \mathrm{L})$ were entered as a between-subjects factor. Analyses of the effects of question number and study programme on the recognition of career counsellor practice show a significant effect of question number, $F(7,2562)=39.81, p<0.001, \eta p^{2}=0.10$, and also on group of students $(\mathrm{H}, \mathrm{M}, \mathrm{L})$, $F(2,366)=4.65, p=0.01, \eta p^{2}=0.025$. The interaction effect was also significant, $F(14,2562)=4.04$, $p<0.001, \eta p^{2}=0.02$. Pairwise comparisons were used for a post-hoc test to investigate the differences between groups of pupils. Pupils from the $\mathrm{H}$ study programme recognized significantly fewer activities of career counselling than pupils from the other two programmes $(p=0.033$ compared to $\mathrm{M}, p=0.018$ compared to $\mathrm{L}$ ). There were no significant differences between pupils from the $\mathrm{M}$ and $\mathrm{L}$ programmes. The exact number of pupils who knew the activities can be seen in Table 1 .

Knowledge of the practice of the career counsellor

\begin{tabular}{llrr}
\hline \multicolumn{1}{c}{ Number of pupils who acknowledge... } & $\begin{array}{l}\text { Group H } \\
\text { N (\%) }\end{array}$ & \multicolumn{1}{c}{$\begin{array}{c}\text { Group M } \\
\text { N (\%) }\end{array}$} & \multicolumn{1}{c}{$\begin{array}{c}\text { Group L } \\
\text { N (\%) }\end{array}$} \\
\hline Someone who will help me to choose the school & $25(22.5 \%)$ & $61(38.6 \%)$ & $34(33.7 \%)$ \\
Knowledge how to make good money & $12(10.8 \%)$ & $11(7.0 \%)$ & $8(7.9 \%)$ \\
Knowledge how to reach promotion at work & $43(38.7 \%)$ & $42(26.6 \%)$ & $32(31.7 \%)$ \\
Skills needed to manage work path & $38(34.2 \%)$ & $36(22.8 \%)$ & $40(39.6 \%)$ \\
Hobbies discover & $17(15.3 \%)$ & $31(19.6 \%)$ & $27(26.7 \%)$ \\
Skills discover & $19(17.1 \%)$ & $45(28.5 \%)$ & $18(17.8 \%)$ \\
Possible jobs & $44(39.6 \%)$ & $111(70.3 \%)$ & $63(62.4 \%)$ \\
Jobs requirements & $36(32.4 \%)$ & $62(39.2 \%)$ & $42(41.6 \%)$ \\
\hline
\end{tabular}

One of the goals of vocational guidance is to measure clients' abilities, interests and personality traits (Savickas, 2015) in order to help him/her to make the most appropriate career decisions (Sears, 1982). In our research only a small percentage of students have chosen this description of career counsellor practice. On the other hand, career means a succession of jobs held, or activities and occupational and other, constituting a life pattern, or occupation (Sears, 1982, 137). Most of the students in our research acknowledged that the career counsellor will present them possible jobs and jobs requirements. Skilled counsellor knows the discipline and provides multiple services to clients. Career counsellor should also be there for students when they may have problems to express and share with their families (Jahn, 2018).

To investigate the counselling activities carried out in schools, we conducted a Repeated Measures ANOVA. The possible activities were entered as a within-subjects factor (repeated measures). Study programmes $(\mathrm{H}, \mathrm{M}, \mathrm{L})$ were entered as a between-subjects factor. Analyses on the frequency of activities showed a significant effect, $F(20,7320)=83.36, p<0.001, \eta p^{2}=0.19$, meaning that some activities are conducted more often than others, the most performed being: preparation of PowerPoint presentations, writing a $\mathrm{CV}$ and public speaking. There was also a significant effect of the study programme $(\mathrm{H}, \mathrm{M}, \mathrm{L}), F(2,366)=4.64, p=0.01, \eta p^{2}=0.025$. Pairwise Comparisons were used for a post-hoc test to investigate differences between groups of pupils. High school students from the M programme carried out significantly more activities than pupils from the $\mathrm{H}$ programme $(\mathrm{p}=0.008)$. The interaction effect was also significant, $F(40,7320)=5.57, p<0.001, \eta p^{2}=0.03$. High school students from different study programmes performed different activities.

Significant differences were also found in those subjects for which students carry out career counselling activities. Repeated Measures ANOVA with subject as a within-subjects factor (repeated measures) and study programmes $(\mathrm{H}, \mathrm{M}, \mathrm{L})$ as a between-subjects factor was conducted. Analyses revealed that there is a significant effect on subjects, $F(8,2928)=165.10, p<0.001, \eta p^{2}=0.31$ but there is not a significant difference between study programmes, $F(2,366)=1.85, p=0.16$. Most activities are 
carried out in social education, information communication technologies (ICT) education, economic subjects, subjects of vocational training and Czech language. The lower proportion of subjects reported by group $\mathrm{H}$ pupils may be related to various scopes in education in apprenticeships, such as less hours for civic education or languages (Rámcové vzdělávací programy..., 2017).

Finally, we conducted an analysis to explore counselling activities practiced by schools. To measure this, a Repeated Measures ANOVA (same factors) was performed. Analyses on the frequency of activities showed a significant effect, $F(9,3294)=68.46, p<0.001, \eta p^{2}=0.16$, which means that some activities are conducted more often than others (Figure 1). There was also a significant effect of the study programme $(\mathrm{H}, \mathrm{M}, \mathrm{L}), F(2,366)=13.01, p<0.001, \eta p^{2}=0.07$. Pairwise Comparisons revealed that high school students from the $\mathrm{M}$ programme carried out significantly more activities than pupils from the $\mathrm{H}$ programme $(\mathrm{p}<0.001)$ and $\mathrm{L}$ programme $(p=0.001)$. The interaction effect was also significant, $F(18,3294)=5.27, p<0.001, \eta p^{2}=.03$. Pupils performed in psychological testing $(p<0.001)$. High school students from study programme M more often performed the last 4 activities (Figure 1).

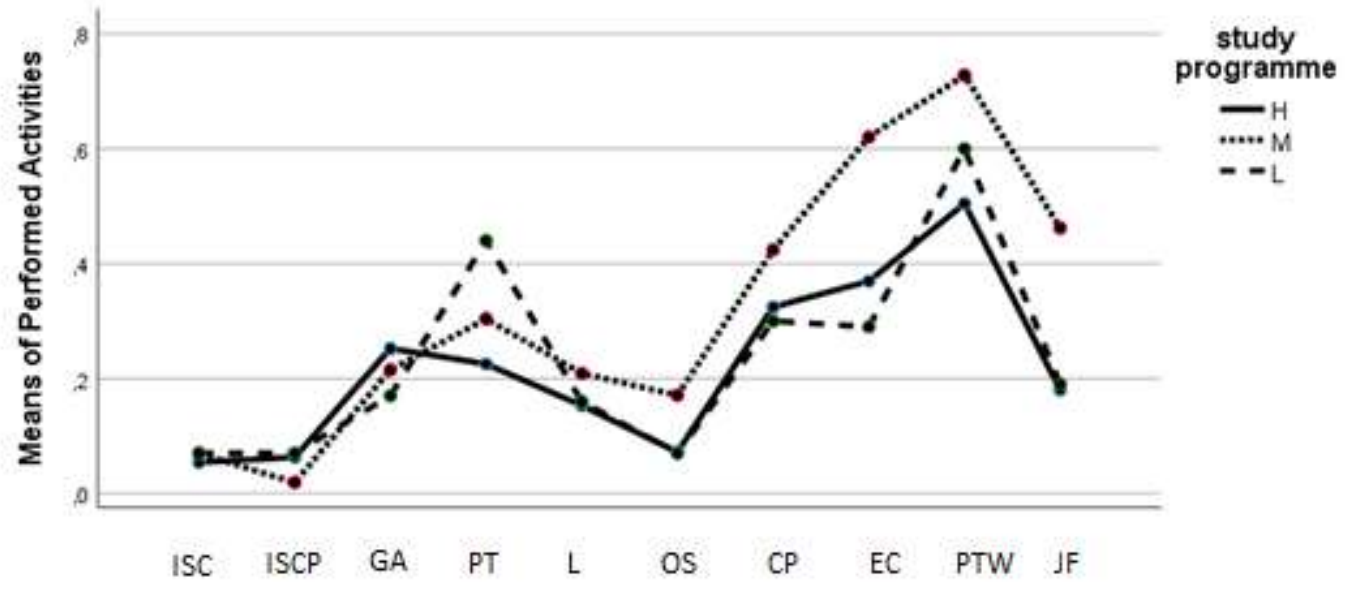

Figure 1. Activities of career counselling performed at schools.

Note: ISC means Individual session with career counsellor, ISCP means Individual session with career counsellor and parents, GA means Career-oriented group activities, PT means Psychological testing, L means Lectures at school, OS means Activities out of school, CP means Presentation of companies at school, EC means Excursions to companies, PTW means Professional training at workplace, JF means Participation at job fairs.

\section{Conclusions}

The aim of the research was to answer the question of how high school students' ideas about CLG differ between categories H, L and M. It turns that the awareness of CLG is lower among respondents from group H. A possible indication is that, in the first studied target group, the segment does not have sufficient support for CLG. Confirming this hypothesis in the wider population and identifying its possible causes is a segment of ongoing research.

The question also included the subjects in which CLG was the most common. It also explored study patterns between groups. Overall, these courses correspond to the structure of the curriculum of secondary technical schools. Some key skills, including those related to career planning and management, are acquired by pupils in general subjects (i.e. civic education, primary/foreign languages, ICT), followed by vocational subjects.

Finally, we observed CLG activities practiced by students of secondary vocational schools and whether there were differences in the experience of students from groups $\mathrm{H}, \mathrm{L}$ and $\mathrm{M}$. In this case, we can make two conclusions. First of all, schools pay little attention to CLG-oriented topics (i.e. determining continuing education and field interest, job exploration, and field-specific employer expectations). On the other hand, teaching and counselling is more often focused on soft skills, such as preparing presentations, performing in public or writing a CV. Secondly, again in this case, it turned out that there is a smaller range of counselling activities for the $\mathrm{H}$ group, which could also reduce their employability and the ability to manage their careers in competition with other high school students in the future. 
Research outcomes are in line with original expectations. Many previous projects and current educational policy should show the impact on students' knowledge and skills in the field of CLG. However, it seems that in pupils of some types of secondary vocational schools are not well prepared to move from school to the world of work and are not learning to manage their future careers. The results also confirm the importance of the ongoing project, which will result in a newly developed methodology for teaching career guidance.

\section{Acknowledgement}

This article was supported by the Technology Agency of the Czech Republic, the ÉTA program under the grant: "Design and Implementation of the Concept and Methodology of Career Learning in Vocational Education" (TL02000256).

\section{Bibliography}

1. Atli A. (2016). The Effects of Trait-Factor Theory Based Career Counseling Sessions on the Levels of Career Maturity and Indecision of High School Students. Universal Journal of Educational Research, 4(8), 1837-1847. doi: 10.13189/ujer.2016.040813

2. Briska L., Dislere V. (2018). Guidance Model for Promoting Self-Directed Career Decision-Making by Secondary School Students. In V. Dislere (Ed.), The Proceedings of the International Scientific Conference Rural Environment. Education. Personality (REEP), 11. Jelgava: Latvia University of Life Sciences and Technologies, 344-353. doi: 10.22616/REEP.2018.042

3. Czech Republic Overview - Key Features of the Education System. (2019) EU: Eurydice. Retrieved from https://eacea.ec.europa.eu/national-policies/eurydice/content/czech-republic_en

4. Diagram of the education system of the Czech Republic 2019/2020. (2019) Prague: DZS. Retrieved from https://www.naerasmusplus.cz/file/5184/cz_schema_2019_20-png

5. Drahoňovská P., Eliášková I. (2011) Analýza práce a potřeb poradců v oblasti kariérového poradenství na školách [Analysis of work and the needs of advisors in the field of career guidance in schools]. Prague: Národní ústav pro vzdělávání. Retrieved from http://www.nuov.cz/uploads/Vzdelavani_a_TP/PORADCI_SKOLY_FINAL_pro_www_opr.pdf (in Czech)

6. Fischer T., Schlimbach T., Attwell G., Balica M., Preisinger-Kleine R. (2011). Careers 2.0: scenarios and personas for technology enhanced educational transitions. In L.G. Chova, D.M. Belenguer, A.L. Martínez (Eds.), The Proceedings of International Conference on Education and New Learning Technologies EDULEARN11, 3. Barcelona: International Association of Technology, Education and Development, 6446-6455. Retrieved from https://library.iated.org/view/FISCHER2011CAR

7. Framework Education Programme for Basic Education. (2007). Prague: VÚP Retrieved from https://planipolis.iiep.unesco.org/sites/planipolis/files/ressources/czech_republic_framework_ed ucation_programme_for_basic_education.pdf

8. Hlad’o P., Drahoňovská P. (2012). Rozhodování žáků základních a středních škol o dalším studiu a práci v pohledu žáků i jejich rodičů. Analýza vlivů sociálního okolí a využití informačních zdrojů na základě dotazníkového šetření. [Decision-making of primary and secondary school pupils on further study and work in the perspective of pupils and their parents. Analysis of the impact of social environment and the use of information sources based on a questionnaire survey]. Praha: Národní ústav pro vzdělávání.: Národní ústav pro vzdělávání. Retrieved from http://www.nuov.cz/uploads/Vzdelavani_a_TP/KP_Volba_zaci_rodice_pro_www.pdf (in Czech)

9. Jahn S.A. (2018). Using Collage to Examine Values in College Career Counseling. Journal of College Counseling 21(2), 180-192. doi: 10.1002/jocc.12096

10. Khorshid E., Alaiwy M. (2016). Education for employment: a career guidance system based on labour market information. In L.G. Chova, A.L. Martínez, I.C. Torres (Eds.), The Proceedings of International Technology, Education and Development Conference INTED2016, 10. Valencia: IATED Academy, 5283-5290. doi: 10.21125/inted.2016.0258

11. Morey-López M., Comas-Forgas R., Mut-Amengual T., Mas-Torello O. (2015). Validation of a questionnaire to analyse the drop-out and engagement itineraries amongst vet students: experts panel results. In L.G. Chova, A.L. Martínez, I.C. Torres (Eds.), The Proceedings of International 
Conference on Education and New Learning Technologies EDULEARN15, 7. Barcelona: IATED Academy, 142-147. Retrieved from https://library.iated.org/view/MOREYLOPEZ2015VAL

12. Multon K.D., Lapan R.T. (1995). Developing Scales to Evaluate Career and Personal Guidance Curricula in a High School Setting. Journal of Career Development, 21(4), 293-305. doi: $10.1177 / 089484539502100403$

13. Národní iniciativa Průmysl 4.0 [National Initiative Industry 4.0]. (2015). Retrieved from https://www.businessinfo.cz/navody/narodni-iniciativa-prumysl-40 (in Czech)

14. Rámcové vzdělávací programy pro střední odborné vzdělávání. [Framework Education Programme for Secondary Vocational School]. (2011-2019). (2017). Retrieved from http://www.nuv.cz/t/ramcove-vzdelavaci-programy-podle-kategorii-oboru-vzdelani (in Czech)

15. Saulite M., Andersone R. (2019). Career Education as a Set of Planned Actions Integrated in the Study Process. In V. Dislere (Ed.), The Proceedings of The International Scientific Conference Rural Environment. Education. Personality (REEP), 12. Jelgava: Latvia University of Life Sciences and Technologies, 303-308. doi: 10.22616/REEP.2019.040

16. Saulite M., Andersone R. (2016). Identification of career management skills related problems in the study process of podologists. In V. Lubkina, S. Usca, A. Zvaigzne (Eds.), The Proceedings of the International Scientific Conference Society. Integration. Education., 1, 221-230. doi: 10.17770/sie2016vol1.1484

17. Saulite M., Koha A. (2017). Purposeful Development of Career Management Skills in the Podologists' Study Process. In V. Dislere (Ed.), The Proceedings of The International Scientific Conference Rural Environment. Education. Personality (REEP), 10. Jelgava: LLU, 466-472. Retrieved from https://llufb.llu.lv/conference/REEP/2017/Latvia-Univ-Agricult-REEP2017_proceedings-466-472.pdf

18. Savickas M.L. (2015). Life-Design Counseling Manual. Retrieved from http://www.vocopher.com/LifeDesign/LifeDesign.pdf

19. Sears S. (1982). A definition of career guidance terms: A national vocational guidance association perspective. Vocational Guidance Quarterly, 31(2), 137-143. doi: 10.1002/j.2164-585X.1982.tb01305.x

20. Śt’astnová P., Drahoňovská P. (2012). Jak žáci základních a středních škol vybíraji svou dalši vzdělávaci nebo pracovni kariéru. Analýza výsledku dotazníkového šetřeni žákù základnich a střednich škol. [How primary and secondary school pupils choose their further educational or professional career. Analysis of results of questionnaire survey of primary and secondary school pupils]. Praha: Národní ústav pro vzdělávání. Retrieved from http://www.nuov.cz/uploads/Vzdelavani_a_TP/AnalyzaKP_ZSaSS_pro_www.pdf (in Czech)

21. Lifelong Guidance Policy Development: A European Resource Kit. (2012). The European Lifelong Guidance Policy Network. University of Jyvaskyla. Jyvaskyla: Saarijärven Offset Oy. Retrieved from http://www.elgpn.eu/publications/browse-bylanguage/english/ELGPN_resource_kit_2011-12_web.pdf

22. Vintere A., Balode I. (2016). Comparative Analysis of the Career Guidance Needs in the Baltic Countries. In V. Dislere (Ed.), The Proceedings of The International Scientific Conference Rural Environment. Education. Personality (REEP), 9. Jelgava: LLU, 275-282. Retrieved from https://llufb.llu.lv/conference/REEP/2016/Latvia-Univ-Agricult-REEP-2016proceed2255-808X-275-282.pdf

23. Vyhláška č. 72/2005 Sb., o poskytování poradenských služeb ve školách a školských zařízeních. [Decree no. 72/2005 Coll., on providing guidance in schools and school facilities]. (2005). Prague: MŠMT. Retrieved from http://www.msmt.cz/file/43482_1_1 (in Czech)

24. Watts A.G., Sultana R.G. (2004). Career guidance policies in 37 countries: Contrasts and common themes. International Journal for Educational and Vocational Guidance, 4, 105-122. doi: 10.1007/s10775-005-1025-y 